\title{
Role of Intraoperative Cholangiography in Laparoscopic Cholecystectomy in Higher Risk Patients of Bile Duct Injuries
}

\author{
SAMIR E. SHNEASHEN, M.Sc.; MOHAMED ELSHEIKH, M.D.; MOHAMED A. HABLUS, M.D. and \\ HAMDY ABDELHADY, M.D.
}

The Department of Gastrointestinal, Liver and Laparoscopic Surgery, Faculty of Medicine, Tanta University

\begin{abstract}
Background: Intraoperative Cholangiography (IOC) during Laparoscopic Cholecystectomy (LC) is a radiologic contrastbased examination of the bile duct which can represent a systemic approach to avoid Bile Duct Injuries (BDIs).

Aim of Study: The aim of this study was to evaluate the protective effect of selective use of IOC during laparoscopic cholecystectomy in patients with high risk for Bile Duct Injuries (BDIs).

Patients and Methods: This was a prospective study included 23 patients who presented for laparoscopic cholecystectomy and had risk factors for bile duct injuries, underwent LC with IOC. Cases were analyzed as regard operative details and clinical outcomes.

Results: Cholangiography was successful in all the cases. The mean time of IOC added to LC was 22 minutes. There was a longer LC and IOC time in cases with positive CRP, pericholecystic fluid, mucocele and pyocele with positive significant differences. Although the pre-operative data $47.8 \%$ had history of obstructive jaundice, $21.7 \%$ a mucocele cases, $17.4 \%$ a pyocele cases, pericholecystic fluid in $30.4 \%$ and dilated CBD in $65.2 \%$, only $13 \%$ showed abnormal IOC and needed further therapies (intraoperative ERCP in 2 cases and CBD exploration in 1 case). No bile duct injury in any case.

Conclusion: Intraoperative Cholangiography (IOC) was found to be safe, taking only an additional time of 22 minutes to total operative time. Although the pre-operative data, only $13 \%$ of cases needed further therapies (ERCP or CBD exploration). The use of IOC could be considered to improve patient safety and long term results.
\end{abstract}

Key Words: Laparoscopic cholecystectomy - Intraoperative cholangiography - Bile duct injuries.

\section{Introduction}

SINCE its introduction by Mirizzi in 1932 intraoperative cholangiography has come to play an

Correspondence to: Dr. Samir E. Shneashen, The Department of Gastrointestinal, Liver and Laparoscopic Surgery, Faculty of Medicine, Tanta University integral role in the surgical management of cholelithiasis and choledocholithiasis [1]

There has been a great debate in the literature regarding the use of routine intraoperative cholangiography. Those surgeons in favor of this practice have argued that it results in a lower rate of biliary tract injury during cholecystectomy, an increased degree of intraoperative detection of common bile duct stones that can be treated at the time of initial surgery, and is a tool for surgical education [2] .

Many other surgeons perform cholangiography only in selected patient scenarios. Recent studies have suggested that there is limited benefit to perform routine intraoperative cholangiography with every cholecystectomy [3]

\section{Patients and Methods}

This was a prospective study, performed in Gastrointestinal and Laparoscopic Surgery Department at Tanta University Hospitals from March 2017-October 2018. The study included 23 patients who presented for laparoscopic cholecystectomy and had risk factors for bile duct injuries. These risk factors are acute cholecystitis, impacted gallstone within the Hartman pouch, Mirrizi syndrome, short or inexistent cystic duct, anatomical variations of biliary or vascular system, thickened gallbladder wall, dilated common bile duct preoperatively, severe chronic scarring of the gallbladder and history of obstructive jaundice.

The intraoperative cholangiograms were obtained as follow: The cystic duct was dissected, the cystic artery was clipped, and exposure of cholecystohepatic triangle, a small stab incision was made on the cystic duct. A 6 french ureteric catheter or silicon catheter was used for cannulation of the cystic duct and injection of contrast material. 
$20 \mathrm{cc}$ of dilute contrast (50\% Hypaque mixed 50/50 with saline) was slowly injected and films were taken.

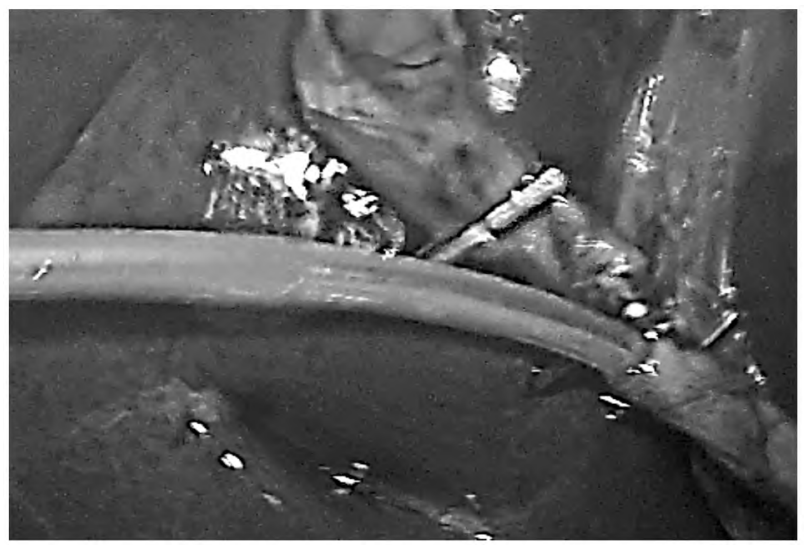

Fig. (1): Cholangiography catheter in place.

\section{Statiscal analysis:}

Data were fed to the computer and analyzed using IBM SPSS software package Version 20.0. (Armonk, NY: IBM Corp). The accepted level of significance 0.05 ( $p<0.05$ was considered significant). $p$-value less than or equal to 0.001 was considered highly significant. $p$-value more than 0.05 was considered non-significant.

\section{Results}

23 patients were included in the study, 11 patients had history of obstructive jaundice $(47.8 \%)$, mucocele in 5 cases $(21.7 \%)$, pyocele in 4 cases (17.4\%), pericholecystic fluid in 7 cases $(30.4 \%)$ and dilated CBD in 15 cases $(65.2 \%)$.

Total operative time was ranging from 40-240 minutes with mean \pm SD $105.1 \pm 61.13$. Longer operative time was noted in cases presented preoperatively with positive CRP, ultrasound showing pericholecystic fluid, mucocele and pyocele with significant difference $0.013,0.037,0.008,0.025$ respectively.

IOC time was ranging from 10-40 minutes with mean \pm SD $22.74 \pm 8.87$. It was found that cases with longer operative time showed also long IOC time. This was clear in cases presented preoperatively with positive CRP, presence of right hypochondrial tenderness and positive Murphy's sign with significant difference as follow 0.019 , 0.019 , and 0.015 respectively.

Also, longer IOC time with cases in which ultrasound findings noted presence of pericholecystic fluid, edema, mucocele and pyocele with significant difference $0.029,0.032,0.009,0.048$ respectively.
Normal IOC, defined as correct biliary anatomy, filling of the duodenum without evidence of common bile duct filling defects, and filling of the right and left hepatic ducts, was found in 20 cases (78\%) Fig. (2).

No cases of bile duct injury was identified intraoperative or presented post-operative, Abnormal IOC findings was found in 3 cases (13\%) as follow:

- First case: Dilated CBD with distal stricture, intraoperative ERCP, Sphinctrotomy was done with good drainage. Fig. (3).

- Second case: Multiple filling defect with distal CBD stricture, intraoperative ERCP, successful sphinctrotomy was done and removal of 4 small stones.

- Third case: Multiple filling defect in CBD, laparoscopic CBD exploration was done and about 5 small stones were removed.

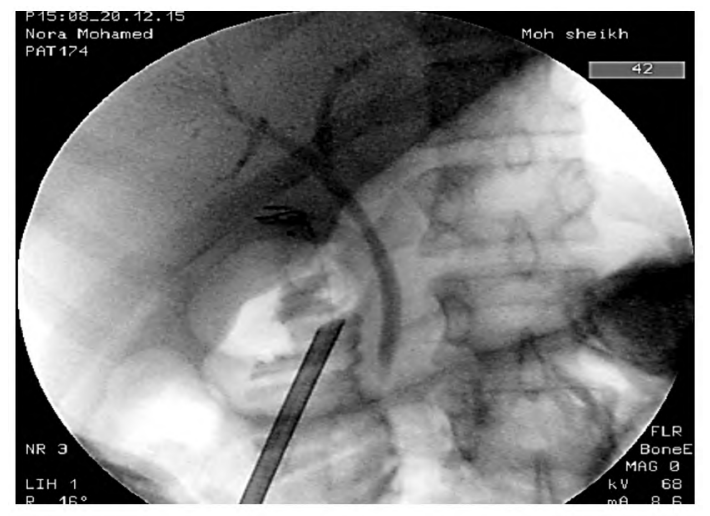

Fig. (2): Normal IOC.

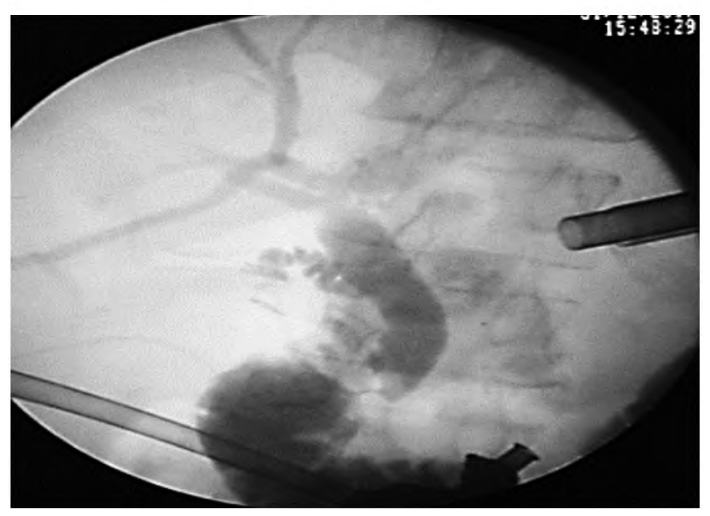

Fig. (3): Dilated CBD.

Out of 12 cases (52.2\%) presented with no history of obstructive jaundice, 11 cases $(91.7 \%)$ showed normal IOC while one case $(8.3 \%)$ showed abnormal IOC and need ERCP. 
11 cases $(47.8 \%)$ had a past history of obstructive jaundice, out of them 9 cases $(81.8 \%)$ showed normal IOC findings, while 2 cases $(18.2 \%)$ showed abnormal IOC and one of them need ERCP and the other case underwent laparoscopic CBD exploration (Table 1).

Table (1): Relation between history of obstructive jaundice and post-operative ERCP $(n=23)$.

\begin{tabular}{|c|c|c|c|c|c|c|}
\hline & \multicolumn{4}{|c|}{$\begin{array}{c}\text { History of } \\
\text { obstructive jaundice }\end{array}$} & \multirow{3}{*}{$x^{2}$} & \multirow{3}{*}{$\mathrm{FE}_{p}$} \\
\hline & \multicolumn{2}{|c|}{$\begin{array}{c}\text { No } \\
(\mathrm{n}=12)\end{array}$} & \multicolumn{2}{|c|}{$\begin{array}{c}\text { Yes } \\
(n=11)\end{array}$} & & \\
\hline & No. & $\%$ & No. & $\%$ & & \\
\hline \multicolumn{7}{|l|}{ IOC findings: } \\
\hline Normal & 11 & 91.7 & 9 & 81.8 & 0.491 & 0.590 \\
\hline Abnormal & 1 & 8.3 & 2 & 18.2 & & \\
\hline \multicolumn{7}{|c|}{ Post-operative ERCP: } \\
\hline No & 11 & 91.7 & 10 & 90.9 & 0.004 & 1.000 \\
\hline Yes & 1 & 8.3 & 1 & 9.1 & & \\
\hline \multicolumn{7}{|c|}{ Lap $C B D$ exploration: } \\
\hline No & 12 & 100.0 & 10 & 90.9 & 1.140 & 0.478 \\
\hline Yes & 0 & 0.0 & 0 & 9.1 & & \\
\hline
\end{tabular}

It was noted that no case with normal IOC findings need post-operative ERCP, and all cases with abnormal IOC findings need ERCP ( 2 cases) and $\mathrm{CBD}$ exploration (one case) Fig. (4).

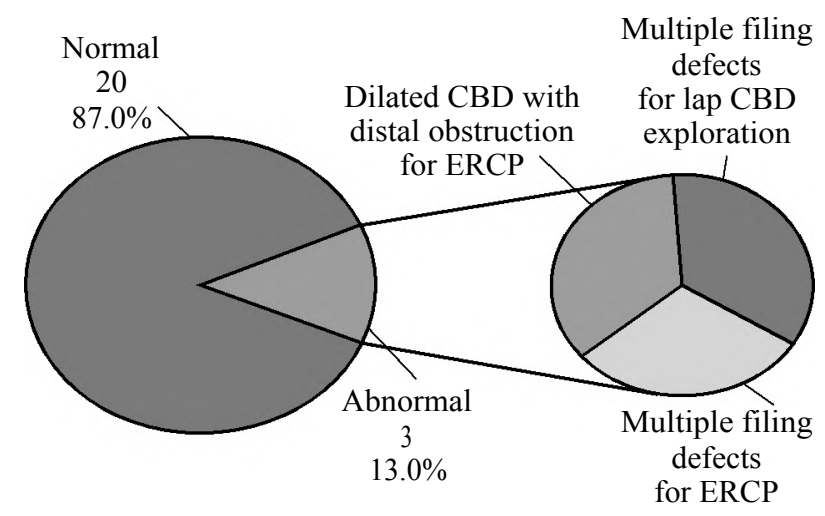

Fig. (4): IOC findings $(n=23)$.

\section{Discussion}

IOC was used selectively for patients with risk factors for bile duct injuries, which coincides with the study as in [4] and against other study as in [5] which reported two hundred thirty five BDIs and there were no risk factors for BDIs in $80 \%$ of patients.

One argument against the use of IOC has been that it prolongs the duration of laparoscopic cholecystectomy. IOC time was ranging from 10-40 minutes with mean \pm S.D of $22.74 \pm 8.87$. It was observed that IOC took a longer time in patients operated during an attack of acute cholecystitis.

Reports of timing for IOC vary based on technique, experience with the procedure, and setting [6] mentioned that IOC time ranged from 17 to $42 \mathrm{~min}$ with mean time of $24.82 \mathrm{~min}$ while in [7] IOC added an average of 28 minutes to total operative time. In [8] IOC time was just over 10 minutes, and in [9] IOC time ranged only from 2 to 16 minutes.

We used a traditional way of $6 \mathrm{FR}$ ureteric catheter or silicon catheter to cannulate the cystic duct without the use of cholangiography clamp. IOC was successful in all included patients (100\%). Cholecystocholangiography was not attempted in any case.

Whether IOC should be performed routinely or selectively for prevention of BDIs remains a matter of debate, the SAGES guidelines for the clinical application of laparoscopic biliary tract surgery [10] recommended that IOC may decrease the risk of bile duct injury when used routinely and can allow access to the biliary tree for therapeutic intervention.

In current study, IOC showed abnormalities in (13\%). Interestingly, (65.5\%) had dilated CBD preoperatively. Out of 11 cases with history of obstructive jaundice, 9 cases showed negative IOC and 2 cases showed positive IOC. This was coincide with other study as in [7] in which IOC showed poor correlation between pre-operative suspicion and confirmed CBD stones (two patients only with preoperative suspected CBD stone confirmed on IOC and ERCP). In [6] IOC showed normal biliary tree anatomy with free flow of contrast into the duodenum in $87 \%$ of cases, while in $13 \%$ of cases IOC showed dilated CBD with free flow of the contrast into the duodenum but with no evidence of filling defects.

As regard BDIs, no cases of BDIs occurred during our study, this results is the same as in $[6,9]$ which performed IOC in 100 patients and 52 patients respectively and both have no cases of BDIs.

In [11] a prospective population-based study of over 1000 patients reported that IOC was feasible in $95 \%$ of cases and had a sensitivity of $97 \%$ and a specificity of $99 \%$ for detecting choledocholithiasis with an incidence of $11 \%$ of choledocholithiasis in that study. 


\section{Conclusion:}

Intraoperative cholangiography can be helpful in prevention and identification of bile duct injuries. IOC is very helpful in cases with suspected choledocholithiasis as it preserve unnecessary ERCP and can facilitate trancystic clearance of bile duct.

While the debate of using IOC whether routinely or selectively is likely to continue, the fact remains that intraoperative cholangiography can provide critical information about biliary anatomy that can be used to guide further surgical therapy.

\section{References}

1- MIRIZZI P.L.: Operative cholangiography. Surg. Oncol., 65: 702-10, 1937.

2- BUDDINGH K.T., WEERSMA R.K., SAVENIJE R.A., VAN DAM G.M. and NIEUWENHUIJS V.B.: Lower rate of major bile duct injury and increased intraoperative management of common bile duct stones after implementation of routine intraoperative cholangiography: J. Am.Col Surg., 213: 267-74, 2011.

3- SHEFFIELD K.M., RIALL T.S., HAN Y., KUO Y.F., TOWNSEND Jr. C.M. and GOODWIN J.S.: Association between cholecystectomy with vs without intraoperative cholangiography and risk of common duct injury. J. Am. Med. Assoc., 310 (8): 812-20, 2013.

4- EIKERMANN M., SIEGEL R., BROEDERS I., DZIRI C., FINGERHUT A., GUTT C., JASCHINSKI T., NASSAR A., PAGANINI A.M., PIEPER D., TARGARONA E., SCHREWE M., SHAMIYEH A., STRIK M. and NEUGEBAUER E.A.M.: Prevention and treatment of bile duct injuries during laparoscopic cholecystectomy: The clinical practice guidelines of the European Association for En- doscopic Surgery (EAES). Surg. Endo., 26 (12): 3003 39, 2012.

5- NUZZO G., GIULIANTE F., GIOVANNINI I., ARDITO F., D'ACAPITO F., VELLONE M., MURAZIO M. and CAPELLI G.: Bile duct injury during laparoscopic cholecystectomy: Results of an Italian national survey on 56 591 cholecystectomies. Arch. Surg., 140: 986-92, 2005.

6- KUMAR A., KUMAR U., MUNGHATE A. and BAWA A.: Role of routine intraoperative cholangiography during laparoscopic cholecystectomy. Surgical Endoscopy, 29: 2837-40, 2015.

7- VERMA S., WICHMANN M.W., GUNNING T., BEUKES E. and MADDERN G.: Intraoperative cholangiogram during laparoscopic cholecystectomy: A clinical trial in rural setting. Aust. J. Rural. Health, 24: 415-21, 2016.

8- BUDDINGH K.T., BOSMA B.M., SAMANIEGOCAMERON B., TEN CATE HOEDEMAKER H.O. HOFKER H.S., VAN DAM G.M., PLOEG R.J. and NIEUWENHUIJS V.B.: Kumar versus Olsen cannulation technique for intraoperative cholangiography: A randomized trial. Surg. Endosc., 27: 957-63, 2013.

9- WENNER D.E., WHITWAM P., TURNER D., KENNEDY K. and HASHMI S.: Actual time required for dynamic fluoroscopic intraoperative cholangiography. J.S.L.S., 9: 174-7, 2005.

10- OVERBY D.W., APELGREN K.N., RICHARDSON W. and FANELLI R.: Society of American Gastrointestinal and Endoscopic Surgeons. SAGES guidelines for the clinical application of laparoscopic biliary tract surgery. Surg. Endosc., 24 (10): 2368-86, 2010.

11-VIDEHULT P., SANDBLOM G. and RASMUSSEN I.C.: How reliable is intraoperative cholangiography as a method for detecting common bile duct stones? A prospective population-based study on 1171 patients. Surg. Endosc., 23 (2): 304-12, 2009.

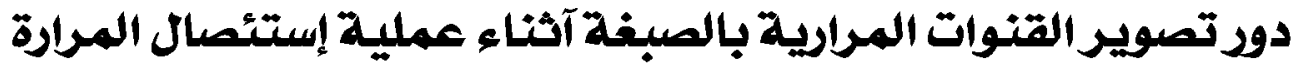

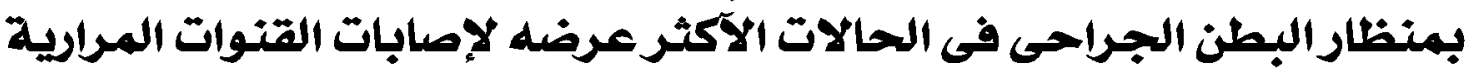

$$
\begin{aligned}
& \text { تصوير القنوات المرارية آثناء إستئصال المرارة هى تقنية هامة فى تعريف الشكل التشريحى القنوات المرارية تستحق التعلم والإستخدام } \\
& \text { الما لها من فوائد متعددة. } \\
& \text { الهدف من البحث: هدفت هذه الدراسة إلى البحث عن دود إستخدام تقنية تصوير القنوات المرارية آثناء عملية إستئصال المرارة بمنظار }
\end{aligned}
$$

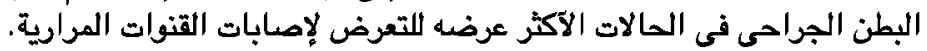

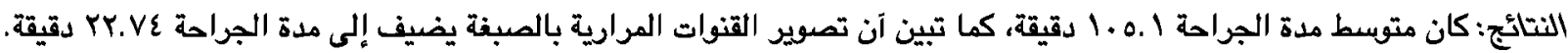

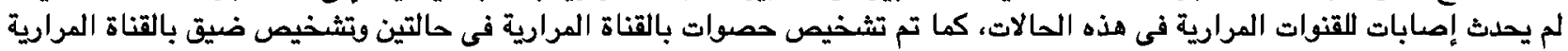

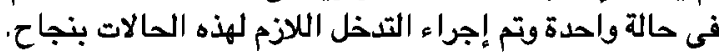

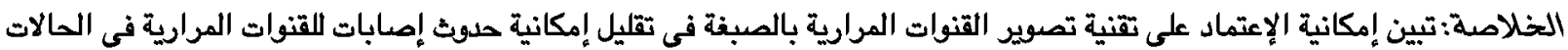

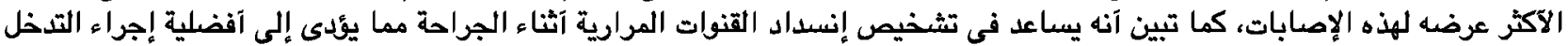

